\title{
The World at her Feet: Cultural Embassy in the Post- War English Ballet Novel
}

\author{
Pamela Knights
}

\begin{abstract}
'Never read a ballet story? Goodness! I've got dozens. Mother buys them for me every birthday and Christmas, though luckily / get lots of book tokens, too, and can buy farming ones for myself. They're always about little girls who want to be ballerinas and who manage it with no effort at all. Madame says she wishes someone would write one when it's made as hard as possible for the heroine and then the poor kid doesn't succeed in the end. But look here! Ifyou're so keen why don't you learn dancing?'

(Allan 1957, pp.24-5)
\end{abstract}

$\mathrm{W}$ Thile texts aimed at children often load tremendous responsibilities on to their protagonists and their readers - to redeem the disasters of history, to safeguard the values of the future - the ballet story is not usually the place over which we conduct our discussions. The genre seems to locate itself dominantly in the sphere of personal aspiration, writing its plots on and out of the body of the young dancer. Such narratives and the questions they raise about subjectivity, gender and sexuality are central to any analysis. But here I shall spend only a short time on these, before moving on to suggest how such private histories might be complemented and extended by attention to some broader public and national agendas within which they are inscribed. There are, indeed, 'dozens' of ballet novels: many early books remain in print and new ones are still appearing (for a brief overview, see Knights 1999, p.35). To keep this paper within bounds, I shall confine myself to some novels produced in mid-twentieth-century England, in the enthusiasm following Noel Streatfeild's path-breaking Ballet Shoes (1936). I shall draw most of my examples from the writing of two of Streatfeild's most active younger contemporaries, who developed the genre after its foundation in the 1930s, and whose major series are still available in revised editions: Lorna Hill, whose interwoven series from the late 1940s to the mid1960 s (including fourteen Sadler's Wells, six Dancing Peel and four Patience books) are the likeliest model for the gift-books inflicted on Jenny in the extract above; and the writer of the passage, her rival, Mabel Esther Allan, best remembered (as 'Jean Estoril') for her ten
Drina books published 1957-65, and an eleventh volume which completed a new edition of the whole series in 1991. These stories are not 'always about little girls'; boys feature in the texts as friends, dance partners and choreographers, with pains taken to reassure readers of their athleticism, courage and normative 'masculine' nature. But until the 1980 s, with the rise of novels more directly confronting entrenched (homo)sexual stereotypes of the male dancer (e.g. Ure 1982), they usually remain a secondary narrative interest. Accordingly. I shall focus here on girls as central characters and as the implied audience.

To become a great dancer is almost always the drean of the girl at the centre of the ballet story. But what kind of aspiration is this? From the moment that the child encounters ballet, the genre follows a peculiarly intense variant of a Romance paradigm, seeking resolution through the integration of the self and the object of desire. Here, ballet represents a separate universe, to which both protagonist and reader crave access, a longing often drawn out over an entire series. The ultimate narrative drive is to place the main character at the heart of that world, both as supreme practitioner and as fetishized artwork, the embodiment of desire fulfilled. Even deviations from the pattern in individual texts depend on this template. The various accidents, obstacles, failures and defections to other interests, careers, lovers or marriage all define themselves against the unattained ideal.

Launching Drina in the self-reflexive critique above, Allan interrogates the conventions, but in this series at least, she could not altogether resist the genre's imperatives. Although she slowed down Drina's ascent, she, too, was forced to reward her protagonist and legitimate her readers' investment (loyalty, commitment, a lot of book tokens) by taking Drina to stardom before the closing volume. While advertising her own superior 'realism', the passage anticipates many of the most common critical objections. Madame, the ballet teacher, dislikes the genre's narrative simplifications, its subjection of its readers to narcissistic fantasies of instant gratification; and the most dismissive commentaries have similarly slighted such stories for 'the scope which they offer for an orgy of self-indulgence' (Cađogan and Craig Copyright Act 1968, copying this copyright material is prohibited without the permission of the owner or its exclusive licensee or agent or by way of a licence from Copyright Agency Limited. For information about such licences contact Copyright Agency Limited on (02) 93947600 (ph) or (02) 93947601 (fax) 
1986, p.300). Jenny, the reluctant ballet pupil who wants to be a land girl, fights off its ideological constraints, the cultural reproduction of acceptable girls' plots imposed on her through her mother's presents and in her enforced dancing lessons. Her complaints hint at the genre's inevitable endorsement of an essentialist model of 'femininity', predicated on impossible (and dangerous) ideals of (white) physical beauty. Such anxieties are shared by some contemporary feminist dance critics and revisionary practitioners (e.g. Hanna 1988) who regard classical ballet itself as an elitist, Eurocentric cultural form, dominated by male musicians, choreographers and directors, where the woman's body is disciplined into a work of art to be held up by her male partner for display to a male critic.

Even at their most troubling, however, these constructions are seldom offered unmixed with other discourses which complicate their impact. As Modleski suggests, popular feminine fictions often simultaneously challenge the ideologies they seem to reaffirm (Modleski 1982). The most serious discussions of ballet novels (e.g. Kuznets 1984-85, Huse 1994, McRobbie 1991) have rightly drawn attention, also, to the power of texts such as Ballet Shoes, as female-centred narratives of professional apprenticeship. ambition and achievement. Streatfeild's influence was far-reaching, tapping into concerns which remain the staple of ballet novels today. Throughout these fictions, the pervasive images of objectified 'femininity', internalized by the protagonist, coexist with more active representations of female energies, focused through the dancer who gains 'expression' and 'authority', commanding her own narrative in the pursuit of her art. In the words of Hill's Veronica Weston, 'Ballet is a perfectly serious career, and not showing off' (Hill 1950, pp.20-1); and the very act of training (in the repeated scenes of lessons. practice and rehearsal) foregrounds social assumptions about the body and the processes of 'performing' ideals of gender in ways that anticipate more recent theories (see especially Butler, 1990). In some texts, this understanding is shared and articulated by at least one of the characters (most famously, Petrova in Ballet Shoes), opening up the chance of dialogue for the reader.

All the heroines' careers raise questions of who and what the dancer actually is, going beyond simple fantasies of grace and glamour. Ballet is a 'vocation', but it's also about sponsorship, business deals, self-marketing. Like Huse and McRobbie, I think it important to recognize the ways such stories offer readers narratives of control, willpower, even ruthlessness, at odds with traditional girls' plots of nurturing, self-erasure, the elimination of ego and autonomy, the harmonizing of the family (see Heilbrun 1988). In post-war 1940s and 50s England, which equated women with domesticity, these novels insisted on girls' rights to independent work and creativity. Hete, girls leave home and family to live in competitive professional communities, knowing that 'You've got to shove in the baliet if you want to get anywhere' (Hill 1953, p.107) Told by her future husband. 'Men are forced to have careers. Women don't have to. . . . It's just silly for a woman to give up everything - friends, beauty sleep, peace of mind - even marriage - for a stupid thing like ballet' (Hill 1951, p.161), Veronica nevertheless establishes her work in the first book of the Wells series and holds her position throughout, long after marriage and motherhood. In the twelfth volume, her daughter is astonished to find her at home: she 'might just as easily have been in New Zealand, or the West Indies, or somewhere.' (Hill 1960a, p.116). Even at their most monologic, these are more densely layered texts than detractors allow, negotiating tensions between different forms of value in the arts, and presenting readers with complex perspectives on the worlds of the dance and on the subjectivity of the dancer. Beyond this, the private story, the making of the self through baliet, is always inserted into larger public and national designs, histories to which the dancer will make a significant contribution. and which her destiny reflects and refracts in peculiarly intricate ways.

Fer the rest of this paper, I shail attempt to tease out some interrelated strands, situating the rising genre in the context of the complex realignments of nationhood after 1945. In the changing post-war world, was England to orientate herself towards the Empire, towards Europe, or towards the nascent Atlantic bloc? What would her mission be? ! shall argue that the ballet story lays responsibilities on young English girls: on the dancer, to take on the role of cultural ambassador on the new world 
stage; and on the readers to be the loyal and inteiligent audience, the true subjects of the future.

Let me start with a moment in Noel Streatfeild's Curtain $U p$ (1944), where Miriam. a young ballet pupil in wartime London, reads a letter from Streatfeild's most famous ballerina. Posy Fossil from Ballet Shoes, whose Hollywood money is now sponsoring Miriam's scholarship. This is no run-of-the-mill letter from a patron, but one with its eye on larger visions. Posy combines excited questions about Miriam's training with warnings from her own mentor, the Czechoslovakian Monsieur Manoff, about the growing insularity of ballet itself:

Choreography in America is now designed for Americans, and choreography in Britain for the British, and in Russia for the Russions, and not, as it was before the war, with an international flavour to suit all audiences. This, of course, doesn't apply to U.S.S.R. ballet which was only intended for home consumption, but America and South America and Britain and most of Europe used to share the Ballet Russe before the war.

(Streatfeild 1944, p.251)

Although Manoff's world-map is undeniably selective, in context Streatfeild's picture of post-war identities is rather more complicated, disrupting singular traditions: significantly, later in the letter Posy mentions how she 'always hated English Literature' (p.251); Miriam comes from a mixed Anglo-Jewish marriage, and Curtain $U p$ as a whole is satirical about English cultural imperialism: 'There's scarcely a corner of the British Empire that has not had to endure your Aunt Marguerite in such parts as Lady Macbeth, for which she's totally unfitted' (p. 122). Within its own time, Posy's letter atternpts to get readers thinking beyond the immediate bounds of national and linguistic heritage. The message by-passes Miriam, who asks Posy to 'please write in littler words next time' (p.252); and Streatfeild's publishers later took this to heart, cutting out these three sentences in subsequent editions. But Streatfeild herself risks taking her own young readers in 1944 into complex issues, mediating for them the kind of contemporary debates aired, for example, in Arnold Haskell's The National Ballet: A History and a Manifesto published the previous year (Haskell 1943). Through Posy, she looks ahead to the role the child might play in the post-war world. If any art could survive the devastating war (and many were worried that it might not), the young dancer would grow up to important responsibilities: rebuilding internationalism through her work in ballet. But would this role be open to a British, or particulariy, an English girl? Could the relatively newly* founded English ballet ever hope to speak, as the French and Russians had seemed to, a universal language on an international stage? And just how 'universal' could such a language ever be? How disinterested were its claims? As Haskell hinted to his readers, promoting excellence carried commercial and political advantages: 'Dancing knows no language barriers, consequently ballet is the greatest shop-window for a nation's art' ( Haskell 1938, pp. 14-15).

Baliet novels, like ballet criticism, persistently represent the art through mixed discourses of aesthetics and economics, patriotism and politics, purity and propaganda. Making movies in Hollywood, Posy sees herself engaged in debased commercial attempts to take ballet to wider audiences; she would greatly prefer to be spending the war years, like Margot Fonteyn, dancing with Sadler's Wells. But for many ballet lovers in 1940s England, the greatest enemy to art was the English character itself. They felt bitter, for example, about the government's conscription of male dancers (already a rare enough commodity); and saw little encouragement to choreographers, such as Antony Tudor, or indeed dancers like Posy Fossil, to work in Britain, rather than taking their art to the United States. P.W. Manchester, in 1942, was unequivocai:

Ballet, like music, speaks a universal language, and England has a new ambassador. Or would have, but that the authorities still look upon art with a suspicious eye, and prefer to truckle to the lowest taste rather than to educate that taste. which might take time, care and a little money. (Manchester 1942, p. 105)

After the burgeoning of ballet in England in the 1930s, such scant official suppert seemed dangesously shortsighted; it seemed the expression of a profound English 
indifference to 'a vital artistic life' which could only build 'a sorry heritage' for the nation (Manchester 1942, p. 106),

Ballet writing in the period expanded in efforts to step into the breach, to educate $E$ nglish taste, and to encourage new audiences (and financial support) for the dance. (In 1946, Manchester herself was to become first editor of Ballet Today). Books for children had the power to make a major contribution; Ninette de Valois knew the importance of well-schooled 'regulars' in establishing a company (Valois 1937, pp.97-109), and ballet stories made a bid to recruit them young. Lorna Hill's Sadler 's Wells series aligned itself with the triumphal histories of de Valois' company which made artistic and national prowess seem inseparable. The North American tour in 1949, de Valois's honour of 'Dame of the British Empire' in 1951, the company's renaming as the 'Royal Ballet' in the Gala Year of 1956: all these, it was claimed, brought prestige to the nation (Davidson 1952, pp.303-4). Book by book, Hill's heroines grew up with Sadler's Wells, making visible in narrative the metaphors through which some writers represented the company itself as a young girl developing through adolescence to maturity, reaching her career accolade in Gala Year. Critics made these tropes personal through appreciation of the rising young English dancers: Margot Fonteyn, in particular (Leith 1942, pp.viii, xiii); Hill, through Veronica Weston and the others who dance alongside. In incremental repetition throughout the series, readers were offered ballet history in the making, in texts and illustrations which merged real-life and fictional icons in legendary stage ensembles: 'I thought I had never seen anything so exotically beautiful as Fonteyn's imprisoned flutterings in the Firebird, or more lyrical than Weston's Odette' (Hill 1960a, p.71).

Novels and histories alike invested readers' hopes in the individual dancer, who, as artist and work of art, promised that the English ballet might one day command the respect of audiences world-wide. Arnold Haskell's bestselling Balletomania typed the great dancer as a valuable 'national treasure'; a 'living and progressive museum of plastic art', 'an active and powertul propagandist' (Haskell 1934, p.159). Haskell, one of the patriarchs of English Ballet criticism, was co-founder of the Camargo Company, and later director of the Wells Ballet School. He produced a stream of books expounding the ballet for adults and children, including a novel, Felicity Dances (1937) with scenes set in the Wells; and his terms remained influential. Here, he summarizes the young dancer's potential: 'If she has the necessary gifts, in spite of her empty little head. she will carry the work of musicians and painters around the globe' (Haskell 1934, p.160).' Though Haskell's rhetoric carried authority (it is echoed in many ballet texts), ballet nove!s arguably offered girls a less stunningly patronising view. The texts invite the reader to establish a special bond with a heroine in her formative years, or to follow her for the whole length of her series; and firstperson narration or close primary focalization makes it hard to dismiss her as merely an empty-headed vessel for male art. On the contrary, at their strongest, these become alternative female quest narratives, offering readers the dancer's own rich story in images of subjective fullness, acquired through the discipline and the languages of the art.

While these fictions enact a significant role in encouraging belief in the potential of the dancer and the dance, ballet in these texts remains a site of contradictions. In the making of a ballerina, the narratives embody the (often conflicting) possibilities of the regional, the cosmopolitan and the universal work of art. Concretized in the genre are features that, as I argue below, suggest the strongly-held dream of an internationalism in aesthetics heard in Posy's letter. At the same time, the texts seem to voice a deeplyrooted English provincialism, both suspicious of art as foreign and dangerous, and profoundly insecure about its own credentials in aspiring to the language of art at all. For P.W. Manchester, Fonteyn's triumph was 'all the greater because acknowledgment of the supremacy of an English dancer is still grudgingly given in ballet circles' (Manchester 1942, p.89). Haskell deplored the 'absurd notion ... that we are a fundamentally inartistic nation', and urged the British to exploit the rich resources of Australia and the Dominions, rather than swallowing more 'European humbug' (Haskell 1943, p.66.). One such colonial treasure, the Wells' star male artist, the Australian Robert Helpmann, was typically described as 'English', (Manchester 1942, p.90). In this context. ballet fictions propose a new cultural mission. Foreseeing the end of Empire. England hands the work of a new 
imperialism to its young people, as dancers or as readers.

As much of this ideological freight is carried in textual elements so familiar perhaps as to seem almost 'natural', I think it is worth sketching some of these items in more schematic form:

1. First, the figure of the 'foreign' parent. For the young dance student. 'foreign' ancestry is not compulsory, but time and again the texts endorse a national geneticist stamp that marks the 'true' or 'born' artist. Like the 1950 s ballet biographies, with their references to Fonteyn's 'Brazilian blood', and Shearer's 'Celtic imagination' (Davidson 1952, pp.85, 260), they emphasise the mystique of origin. In the ballet narrative, this parent is usually safely dead, but remains textually potent, contributing the spirit and the sensitive 'temperament' which code the protagonist's 'difference'. Hill satirizes the view that Russian dancers have "a "fire" the English ones simply don't possess' (Hill 1953b, p.157), but in her texts. this trope often goes unquestioned. In the Wells books, Rosanna and Ella keep faith with their ltalian origins in their difficult rise to glory at Covent Garden (Hill 1956a and 1954a). Annette Dancy in the Dancing Peel series is torn between her home-loving, northern, English side and her French blood (and significant French name: 'd'Ancy'), which leads her to the metropolis and her art:

It was from Mr Dancy that the Dancy childrengot their ornate names and their love of the ballet. After all, didn't ballet begin at the court of Louis XIV th of France? It certainly couldn't have been from their mother, who was English to the backbone - a Northumbrian farmer's daughter. . . as calm and unruffed as Corbie Lough on a still June day [. . .]

(Hill, 1954b, p.44)

But even in these narratives, characters can and do cross national boundaries. most notably in Northumbrian Caroline, who abandons plans for a career in home economics, to transform herself into Rosita, a woridfamous Spanish dancer (Hill 1953a). Various Ukrainian, Greek, or Polish artists live on in Allan's young dancers (e.g. Allan 1971), but her texts also allow space for discussion. Her Drina series foregrounds the issue, in the repeated motif of The Changeling, a ballet which Drina makes her own. Drina's art makes her seem a changeling, a foreigner within her repressed English family, but though her grandmother attributes to Drina's Italian blood all that she fears and seeks to control, the narrative leaves room for difference: as readers learn, it was Drina's English mother who was the ballerina; her Italian father, a quiet businessman. And Allan's final volume, written in the late 1980 s, conciusively dissociates artistic subjectivity from any nationalist or genetic ancestry. Drina, her biographer tells us, is 'her own person' (Allan 1991, p.141).

2. While most children's primary socialization takes place within the family, ballet stories place significant emphasis on alternative institutions, suggesting the possibilities of identity formed outside conventional forms of parentage, class, or nationality. Ballet itself foregrounds the role of cultural memory: a tradition transmitted from teacher to pupil, preserved for the next generation in the body of the dancer. Absorbing a series published over several years, readers themseives become custodians of memories, reinforced in the repeated moment when a young student like Jane (Hill 1952, p.94) realises that she's practising at the very barre where a great dancer like Veronica Weston also started. Through their art, giris enter a strong female lineage embodied in the movements passed on in treasured heirlooms - the dresses, the swan feathers, the worn ballet shoes - that perpetuate the great dancers of the past. These objects gain their significance from their aura of unique presence, of live performances long vanished - a mytheme cynically marketed in the mass-produced pink bracelet or tiny slippers offered free with more recent series (see Barber 1999; Koda-Callan 1989). The inspiration is often the biological mother, herself a ballerina, but by no means always. Girls in these stories find matrilineal kinship in groups that cross genetic, class and national boundaries. Beyond these, interrelated clusters of features, largely figured through travel - the continental tour, or the contact with historic theatres, and with world folk-lore, literature, and music, in the stories of the dance - all these, and more, suggest that in the creation of a dancer, the bounds of nationality will dissolve in art.

The multi-national ballet school itself, like the adoptive 
family in Ballet Shoes, sets the process going, separating the young dancer from her origins. The mixed group of students who live and work together has remained a constant, through the crude racist and national stereotypes of 'Belle of the Ballet' stories for Girl magazine in the 1950 s (e.g Beardmore 1957), to more programmatic. culturally-aware series today. Although the texts present company members as Haskell did, as 'citizens of their miniature Commonwealth' (Haskell 1943, p.64), only more recent fiction intimates that every girl can hope for a role. Even in the more sensitive of earlier texts (those, like Hill's, with an overtly liberal agenda), few non-white characters are significantly individuated, and they rarely receive narratives of their own. A casual aside in Hil reflects her period's cultural realities:

II told Mariella about the students - Canadian Sadie and Isobel, and Lotus Flower (that was what her name meant in English; we called her Lotus for short), the Cingalese girl who was going back to Ceylon toteach dancing. Naturally. being dark-skinned, she hadn't a chance of getting into the Company.'

(Hill 1952, p. 159).

By the late 1950s, Hill can refer to an 'African-born newcomer bringing 'new majesty to the Black Queen'. and her characters perform a new ballet, The Nations (Hill 1958a, pp.41, 135). But the primary function of the colonial and racial Other in these texts remains. nevertheless, as a static frieze to set off the drama of the white English heroine.

3. Related to questions of national identity is the familiar trope of earning a name, which in many ways encapsulates the plot of the ballet novel. As Hil!'s Jane Foster says: 'in ballet you start by being a Christian name and end by being a surname' (Hill 1953b, p.93), the dream of most young dancers in these texts. The issue of adopting a Russian or French name was much debated during the founding of the English ballet companies. The consensus was, as Haskell wrote, that until England had her own tradition, a 'Lizzie Smith' would not dance as well under her own name as she would after symbolic metamorphosis into a Russian artist (Haskell 1934. p.42). Where even Alice Marks had to be transformed into an Alicia Markova, what did the ballet novel suggest to young English readers about their own entitlement to recognition in art? Streatfeild took a lead in Ballet Shoes by the sisters' pride in establishing the Fossil name; and in Curtain Up, Posy is glad to consign 'Posina' to Hollywood, preserving her own name for her career as a truly world-rank dancer after the war (Streatfeild 1944, p.157). Hill, too, allowed English art a title, but selectively. Her respectably-born girls, 'Weston', 'Swan' and 'Foster' keep their English names. But where the lower-class 'Bott' and 'Stout' become 'Browne' and 'Beaucaire', her texts suggest that only certain English classes may be publically legitimised in art. To resolve the problem, both Hill and Allan devised the strategic 'hidden name' plot. a fantastic actualization of Freud's Family Romance: Ella Sordy (Hill 1954) and Drina Adams (Allan 1957) crown their career, and come into their full identity by transforming themselves to 'Rosetti' and 'Adamo', but in so doing, of course, retrieve their true names. 'Andrina Adamo', in particular, with its etymologically doubled male signification, asserts a powerful female appropriation of the source of meanings, the Name of the Father.

4. The alchemist in this process is Madame or Maestro, the heir to Streatfeild's Madame Fidolia. Perpetuating anecdotes about charismatic real-life directors such as Cecchetti and Astafieva (see Haskell 1934, pp.74-75). the muitiaccented teacher, an exile. an aristocrat, a volatile task-master fiercest to those of whom she has highest hopes, survives into baliet novels of the 1990s. Typical are Hill 's Madame Violetta Wakulski-Viret, "part Italian. part French, and part goodness knows what!' (Hill 1950. p. 17), and Ivan Stcherbakof, who 'mixes up the idioms of all the languages', speaking 'nearly every language under the sun' (Hill 1952, p.39), who both praise, shout and swear in whichever suits their mood. Allan rejects the caricature: Drina's first teacher is 'not foreign like most of the teachers in all those idiotic stories about ballet. She doesn't say, "Ah, ze leetle one ees going to be ze dancer most pair-fect!"' (Allan 1957, p.24). And when Drina encounters Marianne Volonaise, who has the PanEuropean pedigree, Allan avoids the comic orthography and broken syntax. But even the grossest stereotyping cannot perhaps quite cancel, for readers, the director's construction as a wise and inspiring figure, the cultural 
link with the legendary baliets of history and the voice of a truly international future: a mentor who, above all, teaches young people. inside and outside the texts, that only by keeping faith with the pure language of the dance will they earn the title of artist.

5. The genre repeatedly suggests that to earn a name in ballet is to enter a new and powerful language. Lorna Hill expanded her series to include the weakest and most vulnerable: ballerinas who emerge from the locked-in silences of orphanhood, poverty and oppression. Anonymous 'Nona', with a bent spine like Taglioni and a harelip, begins to communicate through classical mime (Hill 1959). In an extended revisionary fairy-tale, Ella is transformed from a Cinders in the ashes of a northern pit village to a magical princess at Covent Garden (Hil 1954a). Through learning ballet, Rosanna journeys from the ruins of an earthquake in Amalfi to the world stage:

From five o'clock to six each day she toiled up the steep steps to the Villa Formosa, and practised her plies, her battements, and her port de bras, just as any other little ballei-student practises them in every country in the world, for the art of ballet is universal.

(Hill 1956a, p.28)

Following the disciplined lives of the young protagonists. the reader is inducted into this language in all its forms. She encounters the aesthetic terminology of the dance (as Allan's Mandelina discovers. 'Finding out about ballet meant learning quite a lot of French' (Allan 1971, p.27)): she learns its history and traditions, in repeated scenes where the director tells students the story of the forthcoming production, or recalls great interpretations of a role: she glimpses the great dancers of the past, in comments about the living heritage, enshrined in the ritual exercises at the barre; she gains access to the metalanguage of criticism as the student learns to reflect on the nuances of her art. She confronts questions of what and who the artist is. in the parallel discourses of sponsorship and spirituality that thread these texts. Across the Dancing Peel series, Hill writes Annette into an elaborate plot, ludicrous perhaps, but one which exposes the artist as, variously, commercial property, entertainer, vessel of the past, ambassador and trophy (see especialty
Hill 1955b and 1956b). Allan's Drina, as her teachers recognise, is 'the plum of the ballet world' (Allan 1963, p.153).

6. Beyond and beneath this, the genre engages a further model of meaning. At the heart of this ballet world lies the symbolist ideal of the dancer as both perfect artist and perfect art-work, an expression of the purest of languages, which speaks directly to the spirit across national, cultural and historical divides. One ballet, above all, concentrates this vision of absolute art, and all the problems inherent in it: the version of Les Sylphides, first choreographed as the 'Second Chopiniana' for Pavlova, Nijinksy and Karsavina, in 1909. It was a favourite in the repertoire (there were seven different productions in the 1936 London season alone), but its recurrence in the texts, and its significance for the heroines, goes beyond verisimilitude. With its white, floating figures, its bluelit set, Les Sylphides is consistently presented to child and adult readers alike, as the most poetical of baliets, taking 'a dancer with a very pure line, and faultless technique' (Hill 1952, p.57), a description closely following that of Beaumont (1946, p.82), the dedicatee of Ella at the Wells. For Hill's Princess Fazia, it is the opposite of the political allegories that exasperate her: 'They can't point any morals with Les Sylphides!' (Hill 1962, p.34). Without narrative, without character-parts, this ballet always encodes an image of pure form. For its creator, Michel Fokine, the ballet required 'a special spiritual quality', to grasp its 'hidden meaning' (Fokine 1961 . p.131). Critics seemed to compete to prove themselves true initiates, evoking untranslatable emotions: 'In very truth, one may say that one does not see Les Sylphides; one dreams it' (Borodin 1945, p.66). The wider English public was often found sadly lacking; Ninette de Valois deplored the way people clapped in the wrong places. But she also disliked critics' subjective gush: 'one becomes truly agitated, and can only see yet more worthy British parents deciding that their male offspring shall be bank clerks' (de Valois 1937, p.294). But ballet novels take up the discourse of revelation to construct reader and heroine as the true appreciator, the baliet's spiritual heir.

Repeatedly, even within a single series, Les Sylphides ' moonlit giade and drifting dancers overwhelm the young 
girl in an epiphanic moment, making manifest the impossible ideal of being to which she must dedicate herself. Heroines in Hill and Allan are transported beyond themselves with longing for the sacred grove, the 'fairyglade which I would never enter!' (Hill 1950, p.42). Rapt in the reaim of the absolute, the fernale sublime, E. J. Oxenham's Damaris lapses into silence, 'quivering with emotion which she could not have explained, in the grip of a new experience, a great revelation of the beautiful' (Oxenham 1940, p.51). Here and elsewhere, this language merges the erotic and the mystical to enact the sensual and spiritual moment when the girl weds herself to her art.

The syiph embodies the essence of femininity, as enshrined in fin de siècle and early Modernist aesthetics (for the standard account of this trope, see Kermode 1957). For Gautier, Yeats and others, the dancer was ethereal, mysterious, empty and silent. For Haskell, the apprentice dancer was in the 'sylphide-chrysalis' stage (Haskell 1947, p.7). Few would hatch into a butterfly like Pavlova - as 'little tangible as a figure lightly sketched on a canvas with but a flick of the brush' (Haskell 1934, p.97). One strand of the ballet narrative offers this vision of perfection uncritically to the young girl who wants to become her. As Monsieur Berthelot urges Damaris, 'One day you too will be a sylph' (Oxenham 1940, p.52). The Sadler's Wells series produces dancer after dancer who joins the real-life stars of Covent Garden to replicate the legendary Imperial Russian ensemble. (Near-identical illustrations from book to book highlight the theme.) To be a sylph, this discourse suggests, one must be pure of spirit, body and mind. When depressed, Ella Rosetti "was no spirit of the woods, no sylphide - unless indeed it were the wet English woods in a November fog!'; when recovered, she is as though 'lit up from within ... She was matchless!' (Hill 1955a, pp. 160, 170). Immoral, 'cheap' and secondrate dancers are disqualified. Throughout Hill's series. Belinda Beaucaire always remains at heart the workingclass Belinda Stout, hard, 'vulgar' (Hill 1951, p. 197) and too tainted for the roic. And the (significantly named) European Ballet company distresses Mariella, the daughter of a ballerina and dance-critic. Judging these sylphides under-rehearsed, too fat, too thin, with enormous thighs, and short necks, Mariella winces at their 'very earthily thumps', and pronounces, 'They ought to be prevented by law from dancing in that ballet! It's sacrilege!' (Hill 1952, p.40). But Hill's English heroines live up to the ideal. Veronica's dancing is figured in symbolist images - the fairy of the crystal fountain, a marble statue in a garden (e.g. Hill 1951, p.149) - and at the climax of her most triumphant curtain-call, Hill turns her into the Yeatsian silent dancer. Facing thunderous applause, Veronica is spoken for by her partner: 'Dancers do not speak', he told the audience, 'any more than flowers do' (Hill 1951, p.206). The text implicitly endorses this; shortly afterwards. Veronica falls silent as a narrator, as if once she has entered the glade, she becomes a riddle of remote beauty, to be admired only from afar. As Haskell saw Pavlova, she has become 'a gentle ripple on a pond, the gradual enfolding of a flower' (Haskell 1947, p.85); or, as in the resolution of heterosexual romance narratives, as a woman she is now 'relegated beyond culture and history, firmly placed in the realm of "nature" or "eternal truth"' (Bridgwood 1986, p. 167).

This ideology remains powerful. To 'perform' femininity in the world of these texts is to be cast in a passive role, a spectacle fashioned by the male choreographer, a butterfly pinned in the rapt gaze of the male balletomane. But the texts set up counter-currents. In so doing, they perhaps reconfigure constructions of the female subject, which posit her solely through the objectifiying eye of the male observer (see Mulvey 1975). As in Degas' canvases, readers are variously reminded that the alluring lyric vision is a construction: Haskell's Felicity sees the backstage machinery that creates the 'magic glade' (Haskell 1937, p.45); Allan's heroines meditate upon the human dancer behind the syiph. Hill emphasises that sylphs are career professionals who need ballet companies with money behind them, and who require an educated public. No language is universal; without preparation, aud iences miss the point. The syiphs fail to enchant bored audiences in Scotland and Sicily (Hill 1955b, p.98; 1960b, p.58); boys in the village hall jeer at Annette: they prefer 'boogie-woogie' (Hill, 1954b, p.101). Though Drina dances steps from Les Sylphides by Chopin's grave, her friend Jenny supplies a strong alternative note throughout Allan's series: she consistently mistrusts the baliet's 'unreality' and the demands it makes on the dancer's life. During the series, Allan increasingly 
distances Drina, too, from her favourite ballet. Drina's crisis of faith, which almost ends her career, occurs while dancing Les Sylphides on a winter tour in Manchester (Allan 1965, pp.126-127). Here (in 1965), the ballet momentarily becomes the contemporary theatre of the absurd. Though Drina recovers, she moves on to other ideals of her art. (Significantly, perhaps, at this point Allan set aside the series for over twenty years.)

Such recognitions open other possibilities to girls. Isadora Duncan's critique of the virginal, dematerialised sylph on pointes finds strong advocates in post-1970s novelists. In the wake of second-wave feminism, these openly confront the abuses of the body, anorexia or injury, or convert the heroine to modern dance, where, like Richardson's Moth [. . . heir to Martha] Graham, she can keep her feet firmly on the ground (Richardson 1982). Earlier texts oppose the image with a concern for the artist's full education: where Symbolists suggested the dancer be kept beautifu! by being kept empty-headed. Hill and Allan, like Ninette de Valois, insist that the richest art comes from the richest knowlege, of emotions and intellect (de Valois 1937, pp. 207-210). As Veronica's anxious guardian concedes, "they like educated girls at Sadler's Wells School. The modern idea. I suppose!' (Hill 1950, p.201); while Drina is embarrassed to admit to Miss Volonaise that she reads mostly ballet books (Allan 1959a, p.69).

7. The supreme form of education in these texts is through landscape as heritage. For dancer and reader, the most significant lessons take place outside the classroom, through repeated tropes which seek to resolve the binary oppositions of periphery and centre, regionalism and internationalisin, that preoccupy these texts. In pursuing a universal language. the knowledge which most matters comes paradoxically not from rejecting one's provincial origins, but from a deeper nationalism. A National Ballet needs the 'grit and tenacity' of children from its outlying regions (Hill 1950, p.230). Again and again, the texts propose a kind of tutored Englishness - a deeper education in land and history - which both creates the dancer and redeems English provincialism for international art. Hill's narrative axis, between London and the English/Scottish Border country (extended in a number of texts fully into Scotland), makes all the spheres deeply interdependent. Though to launch a career requires the metropolis, the future ballerina also needs to get in touch with the wild rural spaces or historical sites which commemorate the bedrock of Britain: the strongholds of Northumberland, the ancient geology of the Isle of Skye. Both novelists include informally didactic scenes where Madame visits her pupil in exile in the country, to explain that to love her ancient land will be her making as a dancer. 'Heritage' itself draws on varied geographies, but al! are marked as marginal, and as long-enduring: for Allan's Marianne Volonaise herself, the standing-stones of the French Breton heartland (Allan 1959a p.70); for Hill's Ella, a blighted mining village in Northern England (Allan 1954a); for Joan, a young choreographer, in Allan's The Ballet Family (1963), the English folk-tunes and unique Russian immigrant traditions of the hill towns of industrial Lancashire. In these many-layered signifiers of the country's storied past, the would-be dancers encounter the traces of older, purer, languages - regional dialects, Gaclic, the living legends of the fairies, bogles, and monsters. ('After all, Northumberland is an archaic county. A kind of beautiful, lost forgotten land, where anything can happen' (Hill 1960a, p.113).)

Hill's animal-loving, anti-fox-hunting heroines practise what might now be seen as green ecological thinking, which bespeaks their respect for these old meanings. Veronica wants to express 'the delicate green of the larches, the grace of the foxgloves growing on the Roman Wall' (Hill 1950, p. 104), an ambition achieved in the characteristic metaphors through which the series represents her. Madame sees her come into her art when she dances Les Sylphides in a real northern glade, finding in her work a power wrought by thinking of 'ze woods, and ze 'ills, and ze flowers of zis so-beautifu! Northumberland' (Hill 1950, p.196). Allan takes Drina into the heart of English pastoral in the gentler southern landscape of the Chilterns. Drina, a city-lover, learns to read and absorb the signs of the country's long histories. The Icknield Way, the chalk crosses carved in the hills, the Tudor manors, the litany of names of villages and wild flowers: all permanently enter her artistic consciousness to colour her dancing for ever (Allan 1959a, p.66: an experience recollected throughout the 
series).

Within these texts, what such 'authentic' meanings oppose are the false (but, for youth, supposedly dangerousiy enticing) languages of post-war Britain, which between them menace a humane tradition: modern science, consumer fashion, mass culture, the perceived excesses of a levelling democratization (extended in several plots into diatribes against European Communism). Hill's readers learn that it's 'Impossible to think of atomic bombs, jet aircraft and space rockets here on this quiet moor' (Hill 1960a, p.146), although atomic power threatens traditional mining communities in Hill, and the Welsh hillsides in Allan. Drina's company fails to save a historic theatre; her ballet school is demolished to make room for an office block. Hill's plots indict the cultural impoverishment that is the enemy of art: new money; Hollywood; hire-purchase television; and kitsch such as the flashy statuette of a high-heeled dancer on the suburban window-sill, or the flashy career of the suburban daughter in the Royal Panto (see especially 1954a, p.110 and $1956 \mathrm{a}$, p.96). Within her series, the philistine voice speaks across the entire social scale, but is concentrated. typically, in the socially mobile, the vulgar beneficiaries of a shifting class structure.

For Hill, only the dancer who stays true to older meanings grounded in the English landscape, merits the name of artist. In the afterglow of the Coronation in 1953, her narratives bestow on her ballerinas the seal of approval with a Royal performance. Within the signifying networks outlined above, this climactic moment incarnates, in the new Queen, the icon of a concentrated and idealized Englishness:

It's something inside her that makes her solovely, thought Annette, as she watched the young figure in the glittering white dress pass down the line. She makes you want to cry! It's as if she was dedicated and lit up from within. She completely 'puts out' all of us - even the glamorous film stars. . just as the sun puts out the real stars. (Hill 1956b, p.196)

With such inextinguishable radiance at the centre, Hill's narratives seem to assert the permanence of tradition. In the Dancing Peel series, in a complex series of parallel plots, ali the pure forms at the centre resist attempts to spoil them: the right ballerina gets the star parts, a Scottish castle shakes off the embellishments added by its rich American tenants, the ballet La Sylphide sheds the debased de Cuevas choreography, and the mountains of Skye shrug off a Hollywood film crew (see especially Hill 1958b). But elsewhere Hill faces readers with irreversible historical transitions: the wild spaces are shrinking, cottages are demolished, country children emigrate, the commercial fir-trees planted by the Forestry Commission are edging over the hillsides, and the ballet of the planets, danced in a Lake District Druids' Circle, is monitored by an official from the National Trust (Hill 1959, pp.100-103). (In a historical irony, which Hill would live to see, much of the landscape round Annette's Mintlaw home - celebrated in Dancing Peel's end-papers - was submerged in the 1970 s beneath the massive Kielder Reservoir). At the end of The Little Dancer, Hill looks further ahead. She at last integrates her divided heroine, joining Annette's English side to her French side as she finds herself looking at the Tate Gallery cast of Dégas' La Petite Danseuse. Unlike the mass-produced statue in the suburban front room, Dégas' image is multiple (there are at least thirty in museums around the world) yet still unique, and so has representative force. Annette views the sculpture through the racist categories of 1956, 'Dégas' dancer was ugly, almost negroid'. At the same time, she makes a leap of empathy to override her sense of difference, by identifying herself, and by implication, the text's white readers with the girl and her art: 'There she stood, gazing down the gallery (as she would gaze down the centuries), seeing nothing but her own dreams, typifying all the hundreds of little dancers, of all countries, and all schools past and to come' (Hill 1956b, p.208).

At such moments. Hill's narratives gesture at internationalism, but their general pattern restores her heroines to home in the North country, usually coded through marriages to men from its old houses (typically, mountain-climbing veterinary-surgeons), who love and respect the land. Allan's novels take a different, more radical direction. Though Drina, too, dances like a sylph in the English beech woods, this is just one stage in her development; she doesn't just dance for England. The 
main movement of the series is away from nostalgia for the sacred glade or national glory, to the modern, the secular, and the international. In all her ballet books. Allan's heroines acquire languages, are at home with maps, enjoy cities, love modern art: Drina above all. She collects postcards from galleries: in Paris, she searches out the scenes Utrillo painted.Above all, as her mentor says, 'She's a born traveller - a cosmopolitan. She so soon makes a place her own' (Allan 1962, p.147). The general title format, Drina Dances in ... [place-name], sums up her progress. At the novel's climax, in Italy, Madeira, Switzerland, and the rest. Drina dances, in formal public performance, but more importantly in private, inspired by the beauty of a local scene. Given her position of privilege (white, rich, uniquely talented), this may seem like club-class tourism. But these moments also suggest that her art, like her languages, gives her access to the spirit of place. In Drina's dancing, Allan also hints at a feminist reappropriation of space and geography at odds with the tourist or coloniser. Dancing for herself. even when betrayed by the presence of a male camera. Drina moves beyond the objectified spectacle. In her own ballet, New York Rhapsody (Allan 1964), she brings all her arts together as Allan allows her to be her own choreographer, designer and director. And although Allan reluctantly ended the series with Drina's marriage, she commits her to a new world. Drina marries Grant, an American businessman, in a civil wedding, and refuses to dress like a sylphide (Allan 1991, p.153).

In Hill's The Little Dancer, Annette is told there is still (in 1956) no waxwork of a ballerina in the London Madame Tussaud's. As a joke, she poses as such a statue, but may well. the series implies, become the model for the Hall of Fame in the future. Within these texts, girls who begin by reading ballet novels often end with their names in the baliet chronicles, the subject of dance biographies, paintings, statues, film and television. The series structure itself powerfully reinforces this teleology, as readers take part in the unfolding of history. These stories anticipate England's post-lmperial ambitions of the late century: the new global cultural embassies founded on 'girlpower', charisma, beauty, and the myth of a talent to communicate universally - Princess Diana, ex-Spice Geri Halliwell, dancer Darcey Bussell, and Blair's ${ }^{\circ} \mathrm{Cool}$
Britannia'.

\section{ACKNOWLEDGEMENT}

l'd like to thank Nancy Huse, Rosemary Auchmuty and Linda Hall for their positive responses to earlier versions of this paper presented at: 'Children's Literature and the Fine Arts', ChLA, Paris, 1998; and 'Girls' Career Stories', Lniversity of Westminster, 1999. I'm especially grateful to Sheila Ray for introducing me to Damaris Dances, for letting me read EJO: Her Work (Waring and Ray, 1985, rev. 1997) in typescript and for sharing her extensive knowledge of Oxenham's general ballet contexts - and above all for generously lending me her own collection of vintage ballet novels.

\section{NOTE}

1. For more on Haskell and the 'feminine', see Sayers (1993).

\section{REFERENCES}

Allan, Mabel Esther [as 'Jean Estoril'] (1957) Ballet for Drina. London, Hodder \& Stoughton.

Allan, Mabel Esther [as 'Jean Estoril'] (1959a) Drina Dances in Exile. London, Hodder \& Stoughton.

Allan, Mabel Esther [as 'Jean Estoril'] (1959b) Drina Dances in Laly. London, Hodder \& Stoughton.

Allan, Mabel Esther [as 'Jean Estoril'] (1962) Drina Dances in Paris. London, Hodder \& Stoughton.

Allan, Mabel Esther [as 'Jean Estoril'] (1963) Drina Dances in Madeira. London, Hodder \& Stoughton

Allan, Mabel Esther [as 'Jean Estoril'] (1964) Drina Dances in Switzerland. London, Hodder \& Stoughton.

Allan, Mabel Esther (1963) The Ballet Family. London, Methuen.

Allan, Mabel Esther [as 'Jean Estoril'] (1965) Drina Goes on Tour. Leicester, Brockhampton.

Allan, Mabel Esther (1971) The Secret Dancer. London, Dent.

Allan, Mabel Esther [as 'Jean Estoril'] (1991) Drina Ballerina. Hemel Hempstead, Simon \& Schuster. 
Barber, Antonia (1999) Lucy's Next Stcp. London, Puffin. Beardmore, George (1957) Belle of the Ballet's Country Holiday. London, Hulton.

Beaumont, Cyril W. (1946) The Sadler's Wells Ballet. London, Beaumont.

Borodin, George (1945) This Thing Called Ballet. London, Macdonald.

Butler, Judith (1990) Gender Trouble: Feminism and the Subversion of Identity. New York. Routledge.

Cadogan, Mary and Craig, Patricia (1986) You're a Brick, Angela!: The Girls' Story 1839-1985. London, Gollancz.

Davidson, Gladys (1952) Ballet Biographies. London, Laurie.

de Valois, Ninette (1937) Invitation to the Ballet. London, John Lane.

Fokine. Michel (1961) Fokine: Memoirs of a Ballet Master. Translated Vitale Fokine, edited Anatole Chujoy. London: Constable.

Hanna, Judith Lynne (1988) Dance, Sex and Gender: Signs of Identity, Dominance, Defiance, and Desire. Chicago, University of Chicago Press.

Haskell, Arnold L. (1934) Balletomania: The Story of an Obsession. Londen, Gollancz.

Haskell, Arnold L. (1937; rpt.1946) Felicity Dances: A Children's Tale about the Ballet London: Nelson.

Haskell. Arnold L. (1938) Ballet: A Complete Guide to Appreciation. Harmondsworth. Penguin.

Haskell. Arnold L. (1943) The National Ballet: A History and a Manifesto. London, Adam \& Charles Black.

Haskell, Arnold L. (1947) Prelude to Ballet. London, Nelson.

Heilbrun, Carolyn G. (1988) Writing a Woman's Life. New York, W.W. Norton.

Hill, Loma (1950) A Dream of Sadler's Wells. London, Evans.
Hill, Lorna (195!) Veronica at the Wells. London, Evans.

Hill, Lorna.(1952) Masquerade at the Wells. London, Evans.

Hill, Loma (1953a) No Castanets at the Wells. London, Evans.

Hill, Lorna (1953b) Jane Leaves the Wells. London, Evans.

Hill. Lorna (1954a) Ella at the Wells. London, Evans.

Hill, Lorna (1954b) Dancing Peel. Edinburgh and London, Nelson.

Hill, Lorna (1955a) Return to the Wells. London, Evans.

Hill. Loma (1955b) Dancer's Luck. Edinburgh and London. Nelson.

Hill, Loma (1956a) Rosanna Joins the Wells. London, Evans.

Hill, Lorna (1956b) The Little Dancer. Edinburgh and London, Neison.

Hill, Lorna (1958a) Swan Feather. London, Evans.

Hill, Lorna (1958b) Dancer in the Wings. Edinburgh and London, Nelson.

Hill, Lorna (1959) Dress-Rehearsal. London. Evans. Hill, Lorna (1960a) Back-Stage. London. Evans.

Hill, Lorna (1960b) Dancer in Danger. Edinburgh and London. Nelson.

Hill, Lorna (1962) Vicki in Venice. London: Evans.

Huse, Nancy (1994) Noel Streatfeild. New York. Twayne.

Kermode, Frank (1957) Romantic Image. London, Routledge.

Knights, Pamela (1999) 'Ballet Stories' in Lorna Sage (ed) The Cambridge Guide to Women's Writing in English.Cambridge, Cambridge University Press, p.35.

Koda-Callan, Elizabeth (1989) The Silver Slippers. New York. Workman. 
Kuznets, Lois R. (1984-85) 'Family as formula: Cawelti's formulaic theory and Streatfeild's 'Shoe' books', Children's Literature Association Quarterly 9, 147. $149,201$.

Leith, Eveleigh (1942) 'Introduction' in The Sadler's Wells Ballet: Camera Studies by Gordon Anthony. London, Bles. pp. vii-xiv. -

Manchester, P.W. (1942) Vic-Wells: A Ballet Progress. London, Gollancz.

McRobbie, Angela (1991) Feminism and Youth Culture: From 'Jackie' to 'Just Seventeen'. Basingstoke, Macmillan.

Modleski, Tania (1982) Loving with a Vengeance: Massproduced Fantasies for Women Hamden, Archon.

Mulvey, Laura (1975) 'Visual pleasure and narrative cinema', Screen 16, 3, 6-18.

Oxenham. Elsie Jeanette (1940) Damaris Dances. London, Spring.

Richardson, Jean (1982) One Foot on the Ground. London, Hodder \& Stoughton.

Sayers, Lesley-Anne (1993) " "She might pirouette on a daisy, and it would not bend": images of femininity and dance appreciation', in Helen Thomas (ed) Dance, Gender and Culture.Basingstoke, Macmillan, pp. 164 . 183.

Streatfeild, Noel (1936) Ballet Shoes: A Story of Three Children on the Stage. London. Dent.

Streatfeild, Noel (1944) Curtain Up. London, Dent. [Published in the United States, 1945, as one of a series: Theatre Shoes, or, Other People's Shoes. New York. Random House 1

Ure, Jean (1982) A Proper Little Nooryeff. London, Bodley Head.

Waring, Stella and Ray, Sheila (1985, rev.1997), EJO: Her Work. Loughborough, Waring.

\section{BIOGRAPHICAL NOTE}

Pamela Knights lectures in the Department of English Studies at Durham University, U.K., where she teaches courses in children's literature and American Fiction. She is interested in regionality and constructions of identity and has recently edited Kate Chopin's 'The Awakening' and Other Stories for Oxford World's Classics. She is currently working on a book on ballet novels.

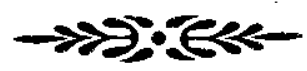

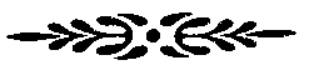

Papers 10: 22000 